\title{
Team-based learning in Physical therapy undergraduate course: experiment report
}

\author{
Aprendizado baseado em equipe na graduação \\ em fisioterapia: relato de experiência
}

\section{Aprendizaje basado en equipo en el grado en fisioterapia: informe de experiencia}

\author{
Juleimar Soares Coelho de Amorim $\oplus^{[a]}$, Bruno Costa Poltronieri $\oplus^{[a]}$, \\ Aline Moreira Ribeiro $\circledast^{[b]}$, Alcindo Antônio Ferla $\circledast[c] *$
}

[a] Instituto Federal do Rio de Janeiro (IFRJ), Rio de Janeiro, RJ, Brazil

${ }^{[b]}$ Centro Mineiro do Ensino Superior (CEMES), Campo Belo, MG, Brazil

[c] Universidade Federal do Rio Grande do Sul (UFRGS), Porto Alegre, RS, Brazil

\section{Abstract}

Introduction: Active learning methods have shown positive results, mainly in terms of content learning and the development of communication skills, critical thinking, and collaborative practice. However, they are still unknown by most professors teaching in Physical therapy courses. Objective: To present the report of an experiment based on the application of the Team-Based Learning (TBL) method, in the Physical therapy undergraduate course. Method: This is a report of an experiment comparing traditional teaching and TBL with 61 students in the Physical therapy course. A comparison was performed between means, medians, approval ratio and satisfaction of the students who experienced the active methodology. Results: The results showed that the final average of the summative evaluations of the TBL group $(71.9 \pm 10.5$ points) was statistically different $(p=0.003)$ from that of the traditional teaching group $(63.7 \pm 9.92$ points). The proportion of approved students was not statistically different between the groups, $92.0 \%$ and $88.6 \%$, respectively $(p=0.478)$. Conclusion: The overall satisfaction was that the method, although tiresome, according to the students, favored a greater

* JSCA: PhD, e-mail: juleimar@yahoo.com.br BCP: MS, e-mail: bruno.poltronieri@ifrj.edu.br AMR: Doctoral student, e-mail: alinemrib@gmail.com AAF: PhD, e-mail: ferlaancindo@gmail.com 
understanding of the content and motivation to study. The study presents innovative results regarding the application of the team-based teaching method to the Physical therapy course.

Keywords: Physical Therapy Specialty. Problem-Based Learning. Interdisciplinary Placement. Hydrotherapy.

\section{Resumo}

Introdução: Metodologias de aprendizagem ativas de ensino têm mostrado resultados positivos, principalmente no que diz respeito à aprendizagem de conteúdos e à construção de habilidades de comunicação, pensamento crítico e prática colaborativa. Contudo, ainda mostram-se pouco conhecidos por professores de ensino em Fisioterapia. Objetivo: Apresentar um relato de experiência com base na aplicação do método Aprendizado Baseado em Equipe (TBL) no ensino de graduação em Fisioterapia. Método: Trata-se de um relato de experiência a partir do ensino tradicional e TBL com 61 estudantes do curso de Fisioterapia. Foram comparadas as médias, medianas, proporção de aprovação e satisfação dos estudantes que experimentaram a metodologia ativa. Resultados: Os resultados mostraram que a média final das avaliações somativas da turma que experimentou o TBL $(71,9 \pm 10,5$ pontos) foi estatisticamente diferente $(p=0,003)$ quando comparado ao ensino tradicional (63,7 \pm 9,92 pontos). A proporção de aprovados não diferiu estatisticamente entre os grupos, 92,0\% e 88,6\%, respectivamente $(p=0,478)$. Conclusão: A satisfação geral foi que o método embora cansativo, segundo os estudantes, favoreceu a maior compreensão do conteúdo e estímulo para estudar. 0 estudo apresenta resultados inovadores em relação à aplicação do método de ensino baseado em equipe para o curso de Fisioterapia.

Palavras-chave: Fisioterapia. Aprendizagem Baseada em Problemas. Práticas Interdisciplinares. Hidroterapia.

\section{Resumen}

Introducción: Los métodos activos de enseñanza han dado resultados positivos, principalmente en términos de aprendizaje de contenidos y de la construcción de habilidades de comunicación, pensamiento crítico y práctica colaborativa. Sin embargo, todavía se muestran poco conocidos por los docentes en Fisioterapia. objetivo: Presentar un informe de experiencia con base en la aplicación del método Aprendizaje Basado en el Equipo (TBL), en el grado en Fisioterapia. Método: Se trata de un informe de experiencia desde la enseñanza tradicional y la TBL con 61 alumnos del curso de Fisioterapia. Se compararon los promedios, medianas, ratio de aprobación y satisfacción de estudiantes que habían experimentado la metodología activa. Resultados: Los resultados mostraron que el promedio final de las evaluaciones sumativas del grupo TBL (71,9 $\pm 10,5$ puntos) fue estadísticamente diferente $(p=0,003)$ en comparación con la enseñanza tradicional $(63,7 \pm 9,92$ puntos). La proporción de aprobados no difirió estadísticamente entre los grupos, con un 92,0\% y un 88,6\%, respectivamente ( $p=0,478)$. Conclusión: La satisfacción general fue que el método, aunque agotador, según los estudiantes, les favoreció una mayor comprensión de los contenidos y el estímulo para estudiar. El estudio presenta resultados innovadores por la aplicación del método de enseñanza basado en equipo para el curso de Fisioterapia.

Palabras clave: Fisioterapia. Aprendizaje Basado en Problemas. Prácticas Interdisciplinarias. Hidroterapia.

\section{Introduction}

Education is a historical and social practice that promotes and participates in culture and society values in each period. Similarly to the time of origin of the Western education tradition, the contemporary society is experiencing a crisis, which is manifested in the current thought and education practices, leading to the necessity for new intellectual models, with suitable pedagogical methodologies and compatible operational strategies. At this moment, however, the development of methodologies and 
instruments is particularly challenging, since other factors have to be considered such as the "nature of education, its purposes, its contents and modes of transmission" [1], generating some controversies.

Therefore, the changes that have occurred in the last few years in our society, resulted from the availability of information sources, globalization, use of technology and the needs, demands and requirements of the job market, along with health public policies in force in the country, presenting a reflection on the dynamics of the learning process and created the necessity for a new look into the health professional qualification [2], including its contents and modes of knowledge transmission. The professional physical therapist is expected to develop abilities and competences that go beyond technical and specific knowledge, comprising, for example: critical thinking, communication, management, resourcefulness, innovation, holistic approach to health care and teamwork [3]. Also, physical therapists are expected to recognize the (social and professional) environments they are inserted in to be able to work in an efficient way, catering for the needs of the population and applying knowledge through practice based on evidence [4].

The current scenery of health professions makes us think about how the education of physical therapists in Brazil is. Teaching methods based on meaningful learning have sought to change the way professors teach "inverted" lessons compared with traditional (or conservative) practices regarding: (I) focus on the learning process, which becomes student centered rather than teacher centered; (II) students' first contact with the content to be learnt; and, (III) critical ability to discuss the content learnt $[5,6]$. This is the proposal presented by the Team-Based Learning (TBL) Method, in which the time in the classroom is mainly used to solve doubts and problems with peers, as opposed to the traditional method that proposes that students learn the contents in classroom and later on, alone at home, dedicate their time to solve doubts that might appear $[5,7]$.

The team work started in the classroom to provide a space for argumentation and contact with different perceptions, which might lead to a better understanding of the contents approached, as well as the development and acquisition of professional skills necessary to the clinical practice [8]. In collective activities, students can solve more complex problems, and, also, the solutions found are significantly better than those produced individually even by the best member of the group [9]. It is essential to prepare students for the collaborative practice throughout their education so that they can work better in teams when they are professionals.

Although active methodologies have expanded in the Brazilian education scenery, the dissemination of successful experiences is still scarce. We believe that they might stimulate and qualify managers and professors for its practical use, producing new assertions and arguments to produce consensus, even if temporary, about ways of thinking and contemporary education practices. Some experiments have been described in the teaching of ethics in Public Health [10], Gynaecology and Obstetrics in Nursing [9], Neurology [11], Medical Education [12], Dentistry [13] and in Graduate Courses $[8,14]$. However, methods that develop collaborative work skills have not been sufficiently explored in the scientific literature on Physical therapy teaching [6]. Therefore, the objective of this study was to present a report of a teaching Physical therapy experiment of using the active methodology Team-Based Learning. The authors' investigation hypothesis is that the methodology adopted presents differences in the subject summative evaluations.

\section{Methods}

An exploratory study was conducted from the analysis of documents registered on the subject Physical therapy Resources III - Hydrokinetic therapy offered in a public institution of the municipality of Rio de Janeiro (RJ) from August to December 2016 (TBL class) and between March and July 2017 (traditional class). Convenience sampling was applied, since the sampling units were chosen due to their availability. Only students that completed the subject were eligible, although they had been approved or failed either by frequency or grade. The study was approved by the IFRJ Ethics Committee (CAAE: 77403317.0.0000.5268).

The Physical therapy course was implemented in the institution in 2009 and is a full time course, offered in the morning and afternoon, it comprises curricular components of a six-month course period with a 60day vacation, 30 days in each six-month period. The 
course is organized based on learning axes, containing the contents according to health problems common to different cycles of life (childhood, adulthood, older age, women and men), stimulating professors to use teaching-learning active methodologies.

This experiment report occurred from the teaching practice in two classes in different sixmonth periods with students of the sixth period of the Physical therapy course. The relevant subject is theoretical-practical and studied in the classroom and part of it was developed in a virtual environment. In one of the classes, the logic that guided the teaching-learning process was based on principles of Meaningful Learning, using the Team-Based Learning (TBL) Method. In the other class, the planned and executed work was based on the traditional method of lessons, also called conservative, which is defined by the professors' verification of accumulated, memorized content, centered in the cognitive and pre-reflexive spheres [14]. In this study, it was characterized using expository lectures with sporadic students' participation.

The active methodology is considered as any teaching activity that provides the students with opportunities of becoming the agents of knowledge construction. The activities are based on the theoretical significant principle of autonomy, as their ability of self-managing or self-governing their own education process [14]. Such concept is important to conceptualize the TBL method, which is based on constructivist principles of collaborative learning and refers to the fact that perceptions and previous experience greatly interfere in the acquisition of new knowledge, highlighting the determining role of the students as active agents of their own learning $[15,16]$. Thus, the professor's role in this context was to indicate paths that the students could follow for their study, acting as a facilitator and inquirer of the contents of the subject.

\section{Phases of the experiment}

Initially, the students were asked to read the subject schedule and contents and a discussion was conducted involving issues related to the teaching method. It seems relevant to highlight that in this first meeting, since TBL teaching was new for both professor and students, they decided that if the expectations were not met or the method was considered confusing, both sides could ask for a revision of the teaching-learning process at any time. The model adopted was based on the experience reported by Livingston and co-workers [17] and planned according to Whitley [18].

The subjects guiding individual and group studies, distance and on site learning were: (I) Hydrostatic, Hydrodynamics and thermodynamics physical principles in therapeutic pool; (II) Physiological effects of the resting immersion; (III) Therapeutic effect of water activity; (IV) Water rehabilitation of neurological, orthopedic and cardiovascular disorders; and (V) Special Topics Seminar on Hydrotherapy. All propositions became a subject of debate in this open space.

The teaching material choice was based on the availability of the virtual scientific literature and the institutional library. At the end of every lesson, book chapters and texts that addressed the content to be discussed during the following lesson were suggested. Also, the search for other digital media and printed material for experimentation such as videos and brochures was stimulated. As such, the knowledge about the choice of study material was built and rebuilt in a proactive action of the participants, guaranteeing opportunities for the selection exercise of literary resources, as well as for the productive dialogue.

Before each lesson, students were invited to study the guiding subject individually (Phase 1 Extra class Previous Study), which was defined as the preparation moment when the students had the first contact with the content. Next, in the classroom, they continued with their individual learning through the contact with an evaluation questionnaire, which contained concepts and problem-situations related to the learning content (Phase 2 - Individual Preparation Test). After this phase, students were divided into groups with a maximum of four members, in which they discussed and decided on the best answer and/or therapeutic procedure for the case content presented (Phase 3 - Team Preparation Test). The professor/ specialist stimulated collective discussion, with an expository approach leading to theoretical-practical reflexion (Phase 4 - Brief Theoretical Exposure). Finally, students decided on their definite answers individually and reviewed them, seeking to reduce 
errors and improve solutions (Phase 5 - Revision). The last part of the lesson was recorded and sent for correction.

Students were evaluated regarding their frequency, accomplishment of tasks assigned by the professor, establishment of constructive and cooperative interactions (feedback), regular participation through theoretical evaluations, customized for each class, and they were responsible for conducting their educational and summative character. The description of evaluation and teaching-learning methods between the groups is showed in Table 1.

Table 1 - Description of evaluation methods and teaching-learning between classes that had lessons using the traditional method and Team-Based Learning (TBL)

\begin{tabular}{ccc}
\hline $\begin{array}{c}\text { Description of } \\
\text { teaching-learning } \\
\text { activities }\end{array}$ & TBL & Traditional \\
\hline Lesson & $\begin{array}{c}\text { Expository- } \\
\text {-dialogued }\end{array}$ & $\begin{array}{c}\text { Expository- } \\
\text {-dialogued }\end{array}$ \\
Intermediary & $\begin{array}{c}\text { 4 TBL sessions } \\
\text { evaluation }\end{array}$ & $\begin{array}{c}\text { Discussion Seminar } \\
\text { DL discussion }\end{array}$ \\
Final evaluation & $\begin{array}{c}\text { Discussion Seminar } \\
\text { DLeoretical test with } \\
\text { the whole content. }\end{array}$ & $\begin{array}{c}\text { Theoretical test with } \\
\text { the whole content. }\end{array}$ \\
\hline
\end{tabular}

Note: Translated and adapted from Livingston [17]. DL: distance learning.

\section{Data analysis}

The total of summative evaluations was presented as a measure of central tendency, dispersion and frequency, using the Chi-Square hypothesis by Pearson for categorical variables and Mann-Whitney for the mean of continuous variables. In all cases, the class that was exposed to traditional teaching was considered as a reference category in relation to the TBL class. A confidence interval (IC 95\%) was estimated and the level of statistical significance adopted was $\alpha=0,05$. The software package Stata 13.0 was used for the data analysis.

Next, students' satisfaction analysis was performed through a standardized instrument. This satisfaction and perceptions analysis about the education process was conducted by the students that had contact with TBL. At the end of the subject, they were invited to answer a semi-structured questionnaire with quantitative and qualitative aspects of the subject and the teaching method employed. The quantitative aspect comprised 36 questions, to which the student would grade from zero to ten, varying from the lowest agreement to the highest agreement with the item. The questions were grouped in the following blocks: (I) subject program; (II) teaching-learning processes; (III) teacherstudents relationship; (IV) evaluation processes; (V) self-evaluation; and (VI) infrastructure. This questionnaire was organized based on the theoretical model in which satisfaction measures comprise the whole education experience and also more specific aspects associated to teaching quality, curriculum, relationship with professors and colleagues, institution facilities and resources, in addition to the students' perception of the academic and intellectual environment where they were inserted.

The qualitative analysis was conducted through two areas of answers: "positive aspects" and "negative aspects" noticed by the students in relation to the subject, teaching-learning process and infrastructure. In this analysis, the theme/category-based content technique described by Oliveira [19] was used to systematize the content of the questionnaires and obtain the central ideas expressed by the individuals regarding the TBL method and the learning process.

\section{Results}

The study had 61 students: 36 (59.0\%) and 25 (41.0\%), in the TBL and in the traditional classes, respectively. Data regarding the students' participation flowchart are presented in Figure 1. In the TBL group, two students (8\%) abandoned the subject or did not attend any lessons, the same occurred with seven students $(19.4 \%)$ in the traditional group. The final average of the classes grades was $71.9( \pm 10.5)$ points and $63.7( \pm 9.92)$ points, in the TBL and conventional groups, respectively. The median of the TBL group (73 points) was higher than that in the traditional group (64.8 points) and was statistically significant $(p=0.04)$. The comparison between the average of the grades obtained showed statistically significant difference in the unpaired t test $(p=0.003)$. Although the averages of the grades had a difference between them, it was not statistically significant in relation to the proportion of students approved $(p=0.478)$, but it was significant regarding the evasion rate $(p=0.012)$ between groups. These results are shown in Table 2 . 


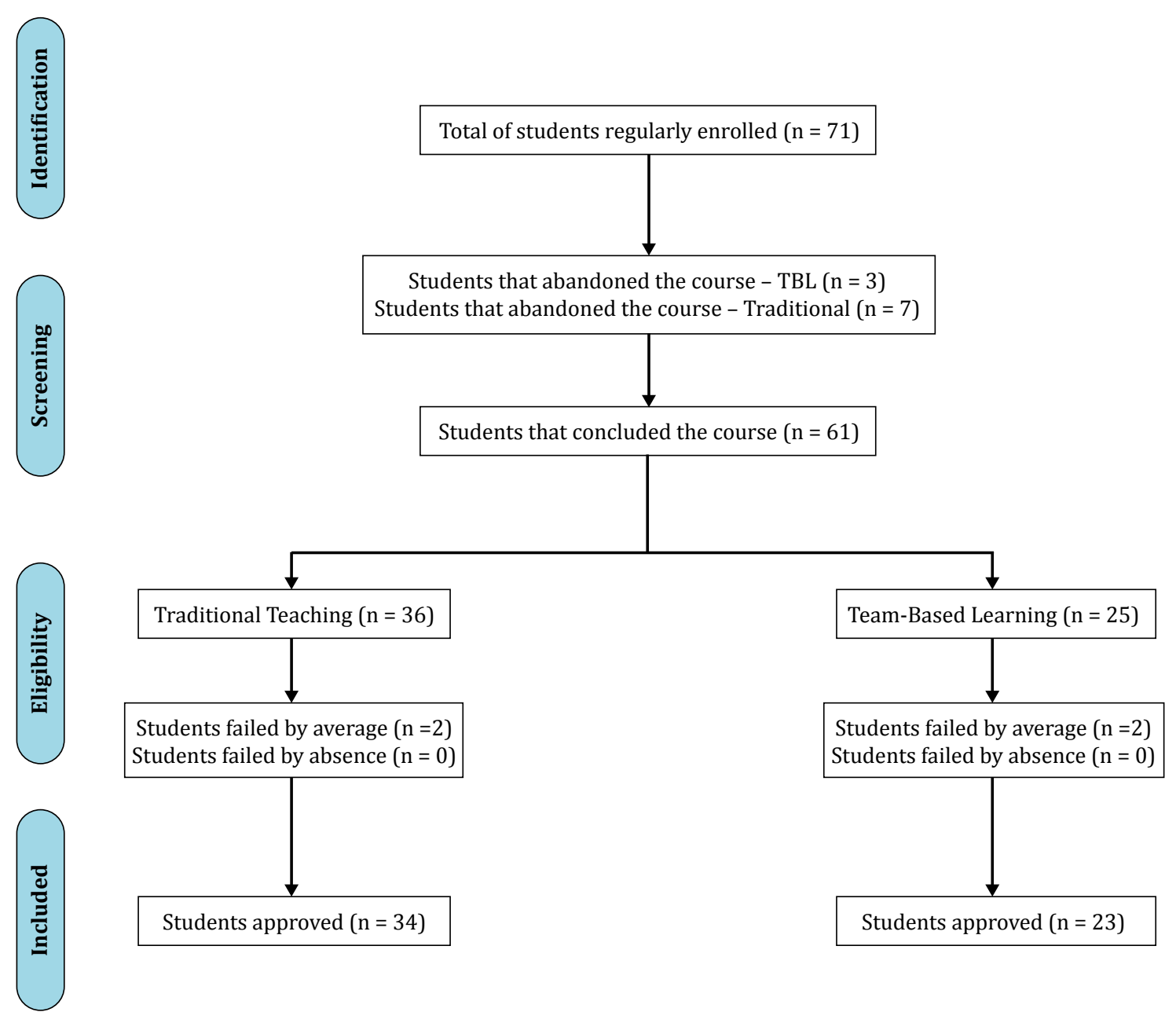

Figure 1 - Flowchart of the selection of students for the study.

Table 2 - Characteristics of the groups that were taught in the traditional and in the Team-Based Learning (TBL) methods

\begin{tabular}{lccc}
\hline \multicolumn{1}{c}{ Characteristics } & $\begin{array}{c}\text { Traditional } \\
(\mathbf{n}=\mathbf{3 6})\end{array}$ & $\begin{array}{c}\text { TBL } \\
(\mathbf{n}=\mathbf{2 5})\end{array}$ & $\mathbf{p}$-value \\
\hline Mean (SD) & $63.7(9.92)$ & $71.9(10.5)$ & 0.003 \\
Median (IQR) & $\begin{array}{c}64.8(60.4- \\
69.4)\end{array}$ & $73(65-79)$ & 0.048 \\
& 11.4 & 8.0 & 0.478 \\
Failure rate (\%) & 19.4 & 12.0 & 0.012 \\
Evasion rate (\%) & 4.0 & 22.2 & 0.470 \\
\hline Attendance ${ }^{\star}(\%)$ &
\end{tabular}

Note: *The attendance considered was the proportion of students who presented $100 \%$ frequency to the classes. TBL: Team-Based Learning; SD: standard deviation; IQR: inter-quartile range (25-75).

Figure 2 shows the statistical difference observed between the conventional and TBL methods in relation to the final average. The variation in the conventional group was seen to be small, however, the lowest and highest grades were around 60 and
70 points. When analyzing the TBL group, however, greater variation was found. Half of the group obtained grades over 73 points.

Table 3 shows data regarding the students' satisfaction. The total mean score was 322.58 points, revealing $89.6 \%$ satisfaction. The aspect with the highest level of satisfaction was the professor-student relationship (94.1\%) followed by evaluation processes (93.0\%). The worst index was ascribed to the infrastructure (65.7\%). Regarding the analysis of discursive responses, in general, student had positive reactions to the method used in the subject, even if some criticism appeared in the total of the evaluations. In a class with 25 students, 14 responses given in the "positive" field were observed and they addressed two inter-related aspects: (I) the evaluation process of the subject conducted in several steps; and, (II) the consequent stimuli received to dedicating themselves and learning more about the contents 
dealt with in the classroom. Such aspects could be observed in responses such as "excellent methodology, segmented evaluations, promoting the understanding of specific content, clarifying lessons" or, even, in the sentence "I could absorb better the contents with the methodology employed".

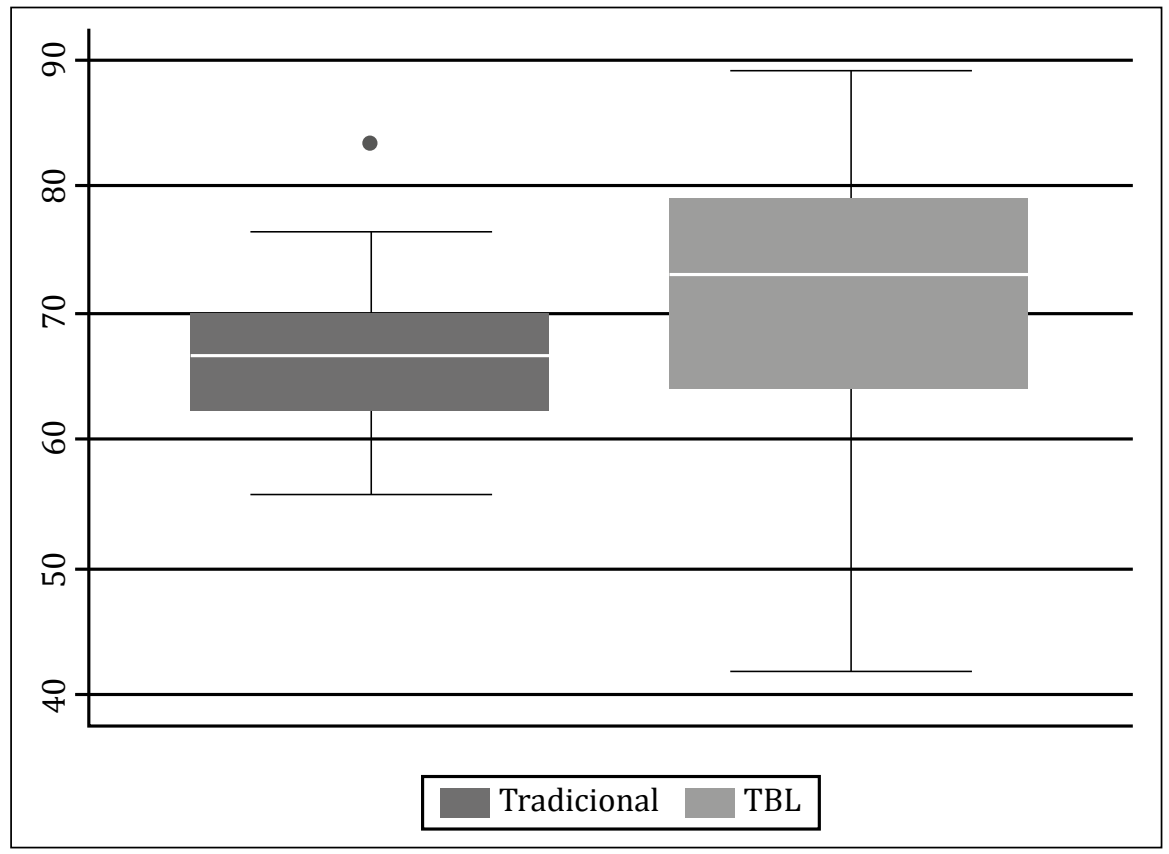

Figure 2-Comparison of the averages between groups taught by the traditional and TBL methods.

Table 3 - Evaluation of the satisfaction of the class taught using the Team-Based Learning (TBL) method

\begin{tabular}{lccc}
\hline \multicolumn{1}{c}{ Category } & $\begin{array}{c}\text { Maximum } \\
\text { score }\end{array}$ & Mean & $\begin{array}{c}\text { Satisfaction } \\
\text { index (\%) }\end{array}$ \\
\hline $\begin{array}{l}\text { Subject Program } \\
\text { Teaching-learning }\end{array}$ & 60 & 55.24 & 92.07 \\
processes & 120 & 10.52 & 91.27 \\
$\begin{array}{l}\text { Professor-student } \\
\text { relationship }\end{array}$ & 40 & 37.64 & 94.10 \\
$\begin{array}{l}\text { Evaluation processes } \\
\text { Self-evaluation }\end{array}$ & 40 & 37.20 & 93.00 \\
Infrastructure & 70 & 63.26 & 90.37 \\
Total & 30 & 19.72 & 65.73 \\
& $\mathbf{3 6 0}$ & $\mathbf{3 2 2 . 5 8}$ & $\mathbf{8 9 . 6 1}$ \\
\hline
\end{tabular}

Regarding the "negative" aspects, eight responses were found. They referred to the fact that the method favors students' overload and mental exhaustion due to the excessive number of evaluations. These notions were expressed in the following responses given by the students, which portrayed the mental wear previously mentioned: "there were too many evaluations, I could not study for all of them the way I should have and the way I wanted, because there were too many" and "One test/evaluation every week (...) makes the students commit and give up the very little (...) free time they have to study throughout the period and manage to get few points. The sensation at the end of the process is that it is a lot of effort for little reward". Therefore, the greatest focus of the students' perception was seen to be the number of evaluations proposed by the TBL method.

\section{Discussion}

The results of this study revealed statistically significant difference in the students' final average when experiencing both the traditional and TBL methods. The median in the TBL group was higher than that in the traditional group, however, the failure rates and attendance were similar between the groups, only evasion rates were different. When students' satisfaction was analyzed regarding the active methodology, the method that was considered tiresome by the students also favored better understanding of the content and stimulus to study. This study presents innovative results regarding the application of the team-based learning in the Physical therapy undergraduate course. The satisfaction results confirm what had been reported by Roh and co-workers [20], who ascribed 
this perception to the mutual collaboration in learning and the dynamic activities developed in teams.

The TBL requires a change of paradigms to learn. Students' responsibility is increased, because they need to work independently, preparing the team sessions, in which they will try to solve problems with their peers. The pre-class learning phase, directed by the professor, might include the reading of teaching books, articles from the primary literature and/or material prepared by the instructors [21]. Thus, the students are assigned some previous study and, next, they are provoked to apply that individual knowledge in a TBL session that might involve concepts, techniques or a clinical case. These two phases require the active participation of the student, which frequently generates resistance to the implementation of this method, since TBL or any other type of active learning involves some change in the passive process of exposure based on lessons which are only attended to [21].

Previous studies have shown that the active methodology has been well accepted in Physical therapy courses, when approaching contents related to the understanding of the health-illness process [6, $15]$ and the results suggest teaching practices that favor a dialogued and critical education [2, 3, 22]. However, little evidence shows the TBL method more specifically for this undergraduate course. Therefore, this investigation is innovative for presenting results about the summative evaluations and students' satisfaction. This study revealed that the content was better retained by the class experiencing the TBL method. These results confirm Elliott's [10] report on Bioethics teaching in a Post-Graduation Course in Public Health, a study by Frame and co-workers [23] in the nursing undergraduate course and another by Fatmi and co-workers [7] in interprofessional teaching in health courses. The TBL approach motivates students to read before classes and be more participative in the lessons. The preparation phase allows the professor to approach and focus on learning gaps, while the teamwork promotes interaction among peers and active learning. These data differ from the study developed with nursing students in the Gynaecology and Obstetrics course, which did not find differences in the students' final averages, possibly due to the characteristics of the course curriculum and the students enrolled [9]. Also, unlike our results, a study developed by Sevenhuysen and co-workers [24] investigated Physical therapy teaching as peer assisted learning compared with traditional teaching, reported students' preference for the traditional teaching without differences regarding students' performance. The authors drew attention to the students' high levels of anxiety, personal stress and reduction in the available time for individual study in this teaching modality.

The results of this experience indicated no difference regarding the proportion of failure between the conventional and TBL groups. These findings confirm previous studies in the literature which, regardless the teaching method, students try to be approved, using memorization techniques and focus on the study on the day before the tests $[9,25]$. Therefore, the traditional teaching method seems not to favor the proportion of approval, but some influence was seen from the way the content is taught and learned.

Regarding the perception of satisfaction with the TBL method, excluding the professor-student relationship, which obtained a better satisfaction index, the items related to the evaluation processes (particular to TBL) obtained excellent score from the students (93.0\%). Students' perception regarding the quality of educational services received (satisfaction) is interpreted as proportional to their expectations in relation to them. The positive aspects that appeared in this experience report, as greater understanding of the content and process learning were also described by Reis [26] in a subject in the Medicine course, which indicated the study routine, the commitment and attendance as aspects that were promoted by the method. Time and tiredness, as negative variables, similarly to this study, were also reported by Soares and Paula [27], in which $80 \%$ of the students in the Engineering undergraduate course stated that the methodology is time consuming regarding task accomplishment, which results in another complaint reported by Reis [26] in which the weekly frequency of tasks was reported to lead students to exhaustion.

The hypothesis that students learn more with the professor or when a teaching method is better assimilated was rejected in a meta-analysis study. Uttl et al. [28] found no association between satisfaction and learning. Therefore, using satisfaction as a criterion of learning evaluation might mistakenly move the focus of students' education. Despite these results, students' satisfaction is important for their better adhesion to the method and the course, contributing to the incentive to learning in relation to searching for information, motivation and dedication of time to the studies, helping critical reasoning, problem solving and preparation for exams [23]. According to Persky [29], the variability in 
the learning rate is explained by the metacognitive selfregulation, but not by personality, attitude regarding one's intelligence, attitude regarding team-based learning, motivation, study skills or the amount of practice. An investigation by Currey [8] reaffirms that students notice their professional growth due to the knowledge and abilities acquired through engagement, learning efficacy, critical thinking, motivation to participate, communication skills in teams and in writing, as well as confidence in the knowledge achieved.

The public teaching institution where this investigation was developed has constantly discussed active methods of learning. A controversial point that serves the basis for the experience of teaching institutions is the current criticism to learning exposure methodologies, mainly regarding understanding of content by the students. In the problematization method, as well as in any other active methodology, the educators are given the role of mediators, making them responsible for helping students to establish relations between technical knowledges and their importance, scope and applicability [21]. However, some effort is required to follow and stimulate the discussion from the learning objectives. Regarding students, the method demands punctuality, attendance and effort to overcome difficulties of interaction and communication, which seems to be more cognitively exhausting. From the institution standpoint, it requires planning and management for a curriculum centered in inquiry, which demands collective efforts for interdisciplinary learning, beyond the diversity of teaching techniques in the classroom.

When the learning through TBL by Physical therapy undergraduate students was evaluated, along with other health courses, Fernandes et al. [30] associated the teaching method to a better collaborative behavior, better preparation for the patients' approach, reduction in the clinical error, improvement of the positive professional identity, clarity of function and attitudes in relation to the other health occupations. In kinesiology teaching to a group of Physical therapy post-graduation students, cooperative learning was seen to be effective to reduce significantly the negative styles of evasive and dependent learning and an improvement in the positive learning style of the participants [31].

The active methodology requires knowledge and abilities from the professor that go beyond the diversity of teaching techniques. Guedes et al. [6] observed that professors that teach Physical therapy practices applied to children used a great variety of instructional resources, such as multimedia, dolls, dynamics, work presentation, practical lessons, curricular internship and clinical case discussions. However, predominantly they observed a focus on the traditional methodology, mainly transmissive. Thus, again, it is necessary a process of change in education, able to break the pre-established structures and models of traditional teaching to qualify autonomous health professionals with a sense of collectivity, who admit an ethical, critical and reflexive teaching practice and, therefore, transforming and exceeds the limits of purely technical training, including the dialectics of actionreflection-action [32].

Finally, in our investigation we observed some strangeness of the subject when understood as the learning trajectory. In the first group, it was not possible to adopt the method due to the students' own preferences, who questioned the fact that the evaluation preceded the professor's teaching. Such strangeness results from the hegemonic model of health education founded on the hierarchy between professor and student, the dichotomy between practice and theory and the struggle to construct different knowledges collectively $[17,22]$. In a pharmacy undergraduate course [21], when the students were first taught through the TBL method and then the traditional method was adopted, they refused expository lessons and showed interest to continue the active method of learning.

There were also a strangeness and a reason for students' complaints about the methodology not being proactive regarding theoretical routine activities of the question and answer type, reading of clinical cases or the production of academic works. Exactly in this environment, TBL seeks to produce, pedagogically, a certain discomfort with what is known, some disturbance regarding the necessity to know how to act. This learning process intends to mobilize and challenge the students to search and be open for the new and the action $[10,17,22]$. The challenge of rupturing with the banking mode of education was present, in the different teaching strategies gathered for certain harmony between what is practiced and what is taught, as well as in the empowerment of students regarding their responsibility to prepare and discuss their learning contents.

The debates about teaching-learning relations made available by the course were an achievement, 
since such discussions tend to be scarce in the Physical therapy courses. For the professor, it was vital to establish a customized dialogue with the students, to know the different practices and their difficulties in the learning developed in the moments of groupwork, to aid the process of knowledge construction from their reflections (set of studies, experiences and perceptions) and to identify gaps in the activation of adversity movements. At the same time, some cohesion was observed between the group participants due to the development of a team spirit, from the elements of a joint mapping. The collectivity axis was developed, which promoted the construction of knowledges from the exchange of experiences and reflections and the support of the course theoretical material.

Even if methodological innovations cannot mobilize the whole teaching institution, the interest in isolated innovative changes within the institution, contrary to the dominant teaching model developed under a technicist and alienating view, might mobilize significant change processes. The TBL method has limitations which should be highlighted and that somehow were expressed in the satisfaction evaluation aspects, which are related to: (I) tiredness and psychic suffering reported by the students, since it requires longer preparation and discussion time and learning conclusion; (II) higher attendance, since missing lessons impacts not only the frequency, but also the opportunity to discuss the content; and, (III) time to prepare and dedicate to the methodology, which is longer. This study did not seek to capture and understand deeply the students' opinions, values and representations of the TBL method, which requires proper analysis. The satisfaction analysis was applied only to the students that experienced the active methodology to understand the aspects inherent in this practice, which is different from the traditional lesson.

Despite the limitations of this study, this investigation aims at motivating new designs of different approaches to understand the experiences lived in the teaching-learning process and the impact of this method in the education of new physical therapists. Further studies are suggested regarding professor's workload, since the method also implies the preparation of more exams, mediation of discussion between the subjects and the preparation of the active methodology. Thus, new investigations might clarify aspects of satisfaction and performance in professors' work plan. Likewise, studies analyzing abilities and competences related to written and oral communication, attitude and intervention plans might cooperate with the understanding of the active methodology as a professional education strategy in Physical therapy.

\section{Conclusion}

The final averages in summative evaluations, the participation in learning moments and the experience revealed new learning challenges of meaningful learning in the Physical therapy teaching scenery. In this study, the TBL methodology showed compatibility with the teaching of theoretical-practical subjects, improvement in the average of grades and reduction in evasion rates but did not show additional benefits related to decrease in failure rates or attendance. These results suggest better preparation in relation to the understanding of the learning content, students' commitment with their own learning, argumentative ability and discussion in groups. New and innovative educational models are necessary to prepare Physical therapy undergraduate students for the practice in collaborative clinical environments, which makes the team-based learning a stimulating educational approach regarding communication skills and collaboration in learning. Students and professors confirmed that their communication and collaboration skills were improved by this format of study. Therefore, this research might be useful for those who consider using TBL to teach Physical therapy.

\section{References}

1. Gauthier C, Tardif M. A pedagogia: teorias e práticas da Antiguidade aos nossos dias. 2nd ed. Petrópolis: Vozes; 2013. p. 28.

2. Weintraub M, Hawlitschek P, João SMA. Jogo educacional sobre avaliação em fisioterapia: uma nova abordagem acadêmica. Fisioter Pesqui. 2011;18(3):280-6.

3. Gauer APM, Ferreti F, Teo CRPA, Ferraz L, Soares MCF. Ações de reorientação da formação profissional em Fisioterapia: enfoque sobre cenários de prática. Interface (Botucatu). 2018;22(65):565-76.

4. Reis FJJ, Monteiro MGM. O ensino na fisioterapia: momento de revermos a prática? Fisioter Pesqui. 2015;22(4):340-1. 
5. Hrynchak P, Batty $\mathrm{H}$. The educational theory basis of team-based learning. Med Teach. 2012;34(10):796-801.

6. Guedes MJP, Alves NB, Wyszomirska RMAF. Ensino e práticas da fisioterapia aplicada à criança na formação do fisioterapeuta. Fisioter Mov. 2013;26(2):291-305.

7. Fatmi M, Hartling L, Hillier T, Campbell S, Oswald AE. The effectiveness of team-based learning on learning outcomes in health professions education: BEME Guide no. 30. Med Teach. 2013;35(12):e1608-24.

8. Currey J, Eustace P, Oldland E, Gianville D, Story I. Developing professional attributes in critical care nurses using team-based learning. Nurse Educ Pract. 2015;15(3):232-8.

9. Moores-Davis TL, Schorn MN, Collins MR, Phillippi J, Holley S. Team-based learning for midwifery education. J Midwifery Womens Health. 2015;60(3):291-7.

10. Elliott S. Using a modified team-based learning approach to teach nursing students about communicable disease control and community health nursing. J Nurs Educ. 2014;53(11):651-3.

11. Yang LH, Jiang LY, Xu B, Liu SQ, Liang YR, Ye JH, et al. Evaluating team-based, lecture-based, and hybrid learning methods for neurology clerkship in China: a method-comparison study. BMC Med Educa. 2014;14:98.

12. Hashmi NR. Team based learning (TBL) in undergraduate medical education. J Coll Physicians Surg Pak. 2014;24(8):553-6.

13. Echeto LF, Sposetti V, Childs G, Aguilar ML, BeharHorenstein LS, Rueda L, et al. Evaluation of teambased learning and traditional instruction in teaching removable partial denture concepts. J Dent Educ. 2015;79(9):1040-8.

14. Mitre SM, Siqueira-Batista R, Girardi-de-Mendonça JM, Morais-Pinto NM, Meirelles CAB, Pinto-Porto C, et al. Metodologias ativas de ensino-aprendizagem na formação profissional em saúde: debates atuais. Cien Saude Colet. 2008;13(suppl. 2):2133-44.
15. Ouellette PS, Blount K. Team-based learning in a graduate nurse residency program. J Contin Edu Nurs. 2015;46(12):572-6.

16. Hermes FC, Cutolo LRA, Maestrelli SRP. A concepção de estudantes de Fisioterapia que participam do ensino baseado em problemas sobre o processo saúdedoença. Rev Bras Educ Med. 2016;40(4):627-34.

17. Livingston B, Lundy M, Harrington S. Physical therapy students' perceptions of team-based learning in gross anatomy using the Team-Based Learning Student Assessment Instrument. J Educ Eval Health Prof. 2014;11:1-10.

18. Whitley HP, Bell E, Eng M, Fuentes DG, Helms KL, Maki ED et al. Practical team-based learning from planning to implementation. Am J Pharm Educ. 2015;79(10):1-12.

19. Oliveira DC. Análise de conteúdo temático-categorial: uma proposta de sistematização. Rev Enferm UERJ. 2008;16(4):569-76.

20. Roh YS, Lee SK, Mennenga H. Factors influencing learner satisfaction with team-based learning among nursing students. Nurs Health Sci. 2014;16(4):490-7.

21. Ofstad W, BrunnerLJ.Team-based learning in pharmacy education. Am J Pharm Educ. 2013;77(4):1-11.

22. Reimschisel $\mathrm{T}$, Herring AL, Huang J, Minor TJ. A systematic review of the published literature on team-based learning in health professions education. Med Teach. 2017;39(12):1227-37.

23. Frame TR, Cailor SM, Gryka RJ, Chen AM, Kiersma ME, Sheppard L. Student perceptions of team-based learning vs traditional lecture based learning. Am J Pharm Educ. 2015;79(4):51.

24. Sevenhuysen S, Skinner EH, Farlie MK, Raitman L, Nickson W, Keating JL, et al. Educators and students prefer traditional clinical education to a peer-assisted learning model, despite similar student performance outcomes: a randomized trial. J Physiother. 2014;60(4):209-16.

25. Arruda RM, Sousa CRA. Aproveitamento teóricoprático da disciplina anatomia humana do curso de fisioterapia. Rev Bras Educ Med. 2014;38(1):65-71. 
26. Reis FJM. Experiência dos alunos do $4^{\circ}$ ano de medicina na aprendizagem baseada em equipes (TBL) na disciplina atenção a saúde da mulher [thesis]. Campo Grande: Universidade Federal do Mato Grosso do Sul; 2015.

27. Soares GA, Paula MR. O uso do team based learning no ensino de cálculo III. In: Anais XII Encontro Nacional de Educação Matemática; 2016 July 13-16; São Paulo, Brazil. p. 1-11.

28. Uttl B, White CA, Gonzalez DW. Meta-analysis of faculty's teaching effectiveness: student evaluation of teaching ratings and student learning are not related. Stud Educat Eval. 2017;(54):22-42.

29. Persky AM, Henry T, Campbell A. An exploratory analysis of personality, attitudes, and study skills on the learning curve within a team-based learning environment. Am J Pharm Edu. 2015;79(2):20.

30. Fernandes AR, Palombella A, Salfi J, Wainman B. Dissecting through barriers: a mixed-methods study on the effect of interprofessional education in a dissection course with healthcare professional students. Anat Sci Educ. 2015;8(4):305-16.

31. Meeuwsen HJ, King GA, Pederson R. Effects of cooperative learning strategy on undergraduate kinesiology students' learning styles. Percept Mot Skills. 2005;101(2):525-30.

32. Park HR, Kim CJ, Park JW, Park E. Effects of teambased learning on perceived teamwork and academic performance in a health assessment subject. Collegian. 2015;22(3):299-305.
Received in 01/02/2018

Recebido em 02/01/2018

Recibido en 02/01/2018

Approved in 04/08/2019 Aprovado em 08/04/2019 Aprobado en 08/04/2019 